\title{
CENTRALIZED RESEARCH IN THE SOCIAL SCIENCES
}

\section{THE CASE FOR RESEARCH IN THE SOCIAL SCIENCES}

\author{
By Prof. GEORGE E. G. CATLIN
}

Sometime Professor of Politics in Cornell University

$I^{\mathrm{T}}$ $T$ is common ground that the task of social reconstruction after the War is going to take a pre rogative position. Upon its success or failure is going to depend the future condition of Europe, and not only of Europe. In the alternative, we shall have not only a revolutionary epoch, but also a revolutionary epoch that is not even successful. The question here is whether this reconstruction is simply going to be carried through by practical men, dominated by the departmental notions of their own personal and limited experience, or whether the politicians are going to call in those who have, as a professional matter, made a systematic survey of the entire relevant data.

There is a second issue which, at the risk of paradox, I would venture to call even more important. It is that of the advancement of science. The social sciences have been embarrassed by the highly emotional and personal nature of much of the subjectmatter with which they have had to deal-although it has been pointed out to me that medical science might have been overwhelmed by the same embarrassment (which has periodically threatened it) if it had lowered its standards of objectivity. To say that every economist is liable to be prejudiced, as the late J. A. Hobson said, is clearly true. To say that therefore there can be no economic science does not follow: The social sciences have suffered from the prejudice of those whose interests were liable to be undermined-so did the physical sciences in their day, but the enemy was then dubbed 'superstition', not 'practical sense'. They have suffered, as Hobbes said, from politicians who regarded them as 'dangerous', and even from eminent universities which have regarded them-as also the physical sciences were once regarded-as undignified upstarts. The great University of Cambridge declined to accept a grant for a chair of sociology, while the ancient University of Oxford had' many, doubtless entirely necessary, chairs of divinity in various forms.

While the social sciences have been regarded as wicked attacks on the humanities by the humanists, they have, alas! been regarded as bastard little brothers by the physical and natural scientists. For some purist academies scarcely anything at all has been science save mathematics and mechanics. For others, no less dangerous, everything capable of being the subject of lengthy meditations has been Wissenschaft and science. As a kind of compromise, when the overwhelming practical importance of these sciences in a disturbed world could no longer be denied, the awakened practical men and journalists asked for 'scientific opinions', and the awakened citizen-scientists began to express their opinions in profusion. Astronomers, biologists and physicists talked about the nature of the State and the rectitude of credit and tariff, as did also the astrologers, and every writer of fiction or belles lettres who had what is called 'a name' and whose articles would sell easily in the commercial, popular press. On the whole, speaking from the point of view (which, of course, has to be considered) of the pay-box, the astrologers led.

For myself, I happen to be a humble political scientist who has spent twenty-two years on the job. The science is immature. Few even of my own colleagues agree with me in everything - but then, neither do the mathematicians agree. That there is a political science I contend along with Machiavelli and Hobbes, Spinoza and Beritham, Mill, Sidgwick, Marx and Lenin. Unlike the last, $I$ hold that it can most helpfully at the moment be provisionally interpreted by the Hobbes-Adler hypothesis of the quest for power and that many of its hypotheses are capable of empirical and quantitative demonstration. These are deep matters, suitable for discussion elsewhere. But, since I put this argument forward (and I admit that it was received with acute scepticism) the work of Bertrand Russell on power, and the revolutionary 'mass observation' studies of Harrison and Madge seem to have done something to confirm it as the tenable hypothesis which alone I submitted it to be.

Political science, however, is perhaps the weakest and most uncertain (although, if Plato be right, the most august and promising) of the social sciences. Whatever be the quarrels of the schools, who will deny that a trained economist is more qualified to discuss economics than a layman ? Or a statistician statistics ? Or a psychologist psychology ?-although I have heard learned humanists at college hightables demonstrating with finger and port glass that experimental psychology was contradictio in adjecto and, moreover, a waste of college funds.

The Social Science Research Council of America, for which I once had the honour of acting as a director of research on the subject of the socio-medical controls under the Eighteenth Amendment, has in its wisdom decided to include, within the field of the social sciences, economics, political science, sociology, anthropology, statistics (including vital statistics), psychology and history. The case of history must seem dubious, since it is generally agreed that there can be no science of history as such, but as a factclassifying discipline the practical advantages of the inclusion of Clio in this company may perhaps outweigh the disadvantages. Plato's rule about the preliminary study of mathematics and Lord Kelvin's rule about the measurable nature of the material of exact knowledge are remembered. As has been well recognized in the School of Human Relations (which owes its establishment in large part to President Hutchins (now of Chicago)), there are various claimants for admission to the circle such as social hygiene on the margins of medicine, and criminology on the outskirts of law. However, the present system works.

This Social Science Research Council began in the United States in the middle of the 'twenties in quite a humble way, with a modest budget. It boasted no offices and not even a salaried secretary, but only a 'secretary to the chairman'. At this time Professors Charles Merriam and Wesley Mitchell played leading parts in getting the organization firmly established. There was little sign of that 'American over-organiz\&. tion' of which my old friend, Professor Graham Wallas, was afraid. Later, first Professor Lynd and then Professor Crane were appointed as secretaries general. The two famous reports on Economic Trends and 
Social Trends were carried through by the Bureau of Economic Research and the Social Science Research Council respectively, the second under President Hoover's patronage and bearing his name as "The Hoover Report". The great prestige of the Council, with its princely offices, is something that has been built up on solid and vital work.

The failure of the Eighteenth Amendment, at great public cost and with inestimable damage to law observance, showed the danger of social legislation and even of 'noble experiments' carried through without adequate psychological understanding or sociological analysis. Nevertheless, it was clear, in about 1929, that there was going to be more social legislation deeply affecting the way of living of the community. The question was whe er it was to depend upon power or upon knowledge, or upon mere muddle and afterthought. Financial aid was obtained from the Halley Stewart Trust in order to establish a preliminary committee to survey the social research work being carried out in Great Britain, as has been mentioned by me in the columns of The Times. Sir William Beveridge, Profs. Carr-Saunders, McGregory, Pigou and Wallas, Lord Stamp, Messrs. Farquharson (rapporteur), Stanley Unwin and others served. Some of us felt that the final report might profitably urge the establishment of a Social Science Research Council of Britain, and this was in some measure done. However, for reasons that need not be discussed here, the broader scheme proved abortive. Largely owing to Lord 'Stamp's activity, the Institute of Economic and Social Research was established, to do valuable work. After talks with Lords Astor and Tweedsmuir and Mr. Tom Jones, the other scheme died. The humanists were not very sympathetic and there was some confusion between the fields of social research and social service, and also doubt whether only economics was mature enough to be regarded as a science.

At the same time suggestions were put forward for a scheme for strengthening legislation by party political research (a matter of interest to Lord Astor and to Mr. Wedgwood Benn, Mr. Roden Buxton, Sir Oswald Mosley and the Fabians) and for a Social Advisory Council to the Government, the latter being put forward in memorandum form in 1930 to Mr. Ramsay MacDonald. Later, the Economic Advisory Council (a very unfortunately constituted body) was established. The design, however, of those who were interested in thus 'rationalizing politics' was not to confound party politics or governmental policy with academic and long-distance research, but precisely, by the establishment of different although related organs, to distinguish these fields of propaganda, policy and research which are so habitually confounded.

For this reason, although I have noted with interest Prof. Patrick Abercrombie's suggestion in The Times, and I believe there is a very strong case for reconstituting the ineffective Economic Advisory Council, I would emphatically not be in favour of establishing any academic council under the Cabinet, and still less (Heaven forfend !) make any Civil Service department. Absolute independence, the staking of personal academic reputations for integrity, the highest standards of objectivity, long-distance researchthese are the requisites. It by no means at all follows that such research has no practical consequences, and this of the most vital character.

I would take research into population changes as one instance. Great prejudices, economic and relig. ious, are stirred. The sovereign pride and the national and racial rivalry of States are affected. It is all very difficult - and all very practical. The final war is the biological war. Many of the facts are matters of 'cold' statistics, although, of course, ultimate questions of values do not come within the purview of science. The medical man, for example, works on the hypothesis that the life of the patient should be preserved. There may be occasions when morally it should not. It is outside his province to decide the morals of infanticide but only to carry out the Hippocratic oath. That is his hypothesis.

There is probably a strong case' for establishing an Institute of Vital Statistics, Demography and Social Biology. But no departmental institute can fulfil the work of the Council, nor can the institutes representative of other departments - anthropology, sociology, experimental " psychology, industrial psychology or the various societies such as the Royal Historical Society be expected to serve under its banner. A general council is required.

On the analogy of what has already been done or recommended, I would suggest that the functions of a Social Science Research Council should be $(a)$ to survey the field of the social sciences and to prevent overlapping in research ; $(b)$ to provide a channel of financial aid from individual benefactors, public foundations and the Government; (c) to pass upon and initiate schemes for research; (d) to provide finance and aid in the provision of personnel and office facilities for such research; $(e)$ to publish, where desirable, the results; $(f)$ generally to promote the interests of, and to advance, the social sciences; $(g)$ to be an organ for voicing the collective opinion of social scientists on such occasions as it may be desirable to express them; (h) to represent the social scientists of Great Britain at relevant international gatherings ; (i) to aid the Government and appropriate public bodies in social scientific research, when called upon to do so. I do not contemplate the Council members themselves being called upon, as such, to undertake research. This should be done by individual experts who are recognized authorities in their special subject, a background of advisers being supplied by sub-committees ad hoc. The function of the Council should be initiatory and generally supervisory.

The constitution of the Council involves more difficulties in Britain than in the United States, where every discipline has its own national association. I would, however, suggest that every holder of a chair or a readership in the selected subjects in the British universities should be ex officio a member, and probably also the directors of the relevant institutes and the presidents of the recognized national societies. It will be borne in mind that their main executive function, apart from the raising of funds, which can be left to the officers, would be the appointment of vigorous sub-committees to do. the actual work. A special relationship would need to be established with the Royal Society, the British Academy and the British Association. But the less the American model, in constitution, is departed from the betteralthough, of course, a British institution can be expected to operate in a typically British rather than a typically American way.

The establishment of such a body, such as would gratify a Petty or others of the founders of the Royal Society, might well be one of the greatest steps for the advancement of science and one of the most original contributions to far-sighted and reasonable government in our century. It could do something to vindicate democracy as government by discussion, 
comment and reason, against government that claims to be efficient but rests on the principle of mere party power. Before there can be what is readily called 'scientific government' (be it 'scientific socialism', 'scientific business', or what have you) there must first be science, not apologetic but organized, independent, authoritative.

\section{BIOLOGY AS A SOCIAL SCIENCE}

\section{By MRS. S. NEVILLE-ROLFE, O.B.E.}

$I^{\mathrm{F}}$ a social structure that provides for the emotional 1 freedom and development of personality is to be the outcome of the present struggle, then an immediate effort must be made to harness individual emotional energies to this purpose. If the present world-wide destruction of man and his material assets by his fellow-men is not to inflict irreparable damage on civilization, man must make a supreme effort to safeguard and improve human quality. $\mathrm{He}$ must collate his seientific and spiritual values -to this end the gulf between the scientific and extra-scientific leaders must be spanned by as wide a bridge of common agreement as possible-direct his knowledge and energy to the fostering of individual emotional maturity and to the conscious control of his own evolutionary processes. Both intellect and emotions must be mobilized in the pursuit of a satisfying purpose in life, by applying to man the existing knowledge of social biology and by directing the desires and capacities of the present generation to further research (related to man) on personal and genetic development.

The knowledge and experience drawn from all parts of the world and from all groups working on biological problems-both theoretical and practical - should be immediately collated by an organization designed to promote its application and to foster further research.

To this end it is suggested that an institute having social biology within its purview should be called into existence, representative of scientific thought and world-wide experience, and able to act in a consultative-directive capacity.

Social biology is interpreted, for the purpose of this article, as including all those branches of science and administration directly concerned with man in relation to the genetic, traditional and environmental factors that shape his personality and influence his social relationships.

Many branches of general biology have contributions to make, including functional anthropology, ginetics, psychology, physiology and biochemistry. The educationist, sociologist and statistician are also needed as channels of application as well as the administrator, the statesman, the medical man and the judiciary.

The time-lag between knowledge and practice in its application to the quality of man himself is unduly long. If the causes are recognized, it may hasten their removal.

\section{Social Effects of Unrecognized Biological Factors}

It has in recent years become obvious to some of our Empire administrators that man is being shaped to a large extent by his environment. The effect of soil erosion on tribal customs ; the effect on nutrition, and ultimately on fertility, of relating currency to cattle; the effect of soil starvation and overrecruiting of labour on tribal and family life; the break-up of tribal life brought about by intellectually imposed changes in spiritual values-all are problems of social biology and are now seen by some with clarity for what they are.

We recognize the effect of imposing Western factual knowledge on peoples whose emotional values are still governed by tribal tradition. We can see the results of this unconscious but large-scale experiment in social biology among the detribalized Africans living in ports and industrial towns. Their emotional lives rooted in the traditions and governed by the values of the tribe, its family structure, its land tenure, its totems and its magic are not integrated with the newly acquired factual knowledge, or with the required behaviour pattern of a more complex culture. Unless these former deep-rooted and emotionally desired standards and customs are carefully re-interpreted and related to the higher values embodied in the European culture it is sought to impose, so that these are willingly accepted, there is deterioration in character, personal unhappiness and a sense of frustration. Some apparently successful experiments in social biology have alrearly been made-for example, the substitution of competitive prowess in the hunt or in sport for the hearl-hunting qualification for full tribal membership and marriage, and the modification of the original mutilating initiation ceremonies to a form adapted to the ritual entry to a Christian community.

While we recognize the emotional childhood of the African and rightly explain his irresponsibility as due to the personal conflict between his own values and new knowledge, we have not recognized the same conditions as"obtaining in ourselves.

Psychology, anthropology and endocrinology have of recent years widely extended our understanding of the emotional nature of man. Many well-known phenomena hitherto quoted as evidence of the 'unchangeability of human nature' are now seen as the result of infantile desires being unrecognized as such by the intellect and remaining as overshadowing influences or subconscious prejudices often impelling the adult to behaviour entirely at variance with the dictates of reason. A factor of supreme importance, but not yet consciously applied, is that the first appreciation of 'values' comes through the emotions. An intellectual giant may be gravely frustrated in personal life by an uncontrolled temper, arising from subconscious emotional causes, or by an emotional immaturity which denies him the harmony of adjustment in marriage.

Human energy has been directed to training the intellect but has ignored the emotions. Knowledge will not affect behaviour or lead to action until implemented by emotional driving force, which can only be secured when both mind and emotion accept a common objective and purpose in life. Though this is known to the psychologist, it is not adequately applied by the educationist, nor is it generally understood by the public.

\section{Emotional Development of the Chi'd}

The Child Guirlance, the 'Home and School' and the Mental Welfare Councils, and a number of individuals are working out techniques for the emotional development of the child, on the basis of existing knowledge, and indicating lines of research and inquiry. 